
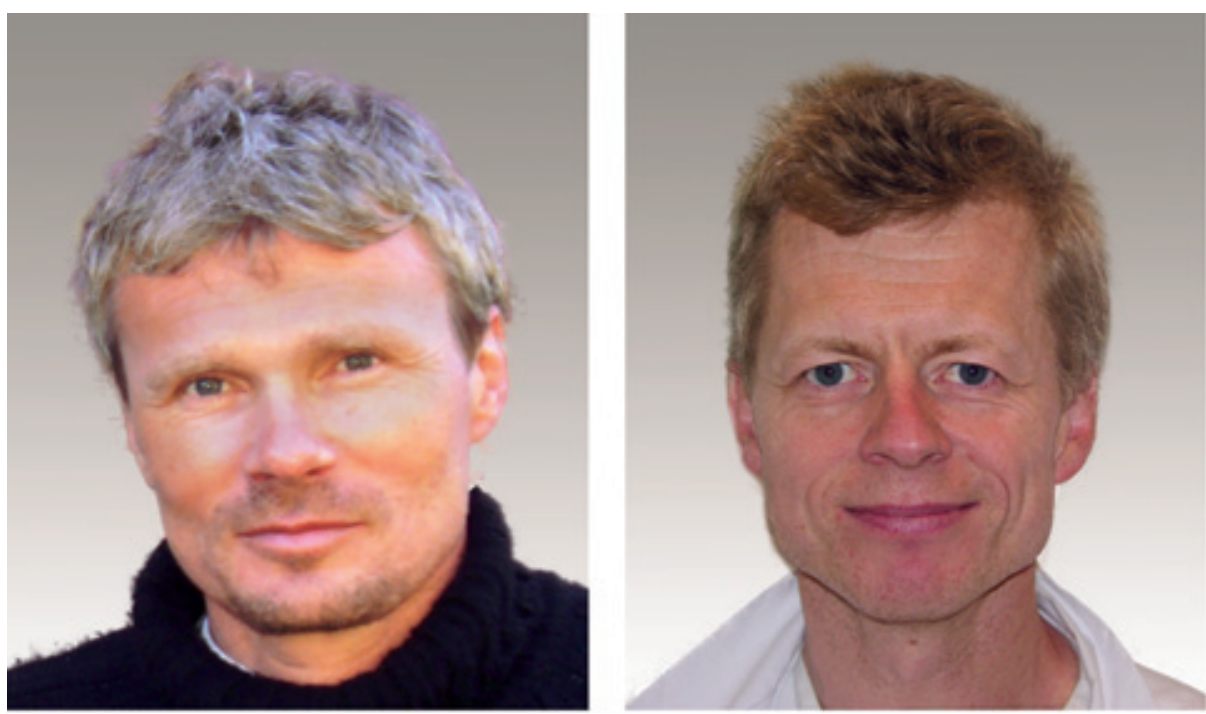

Førsteforfatter Christian Hellum (til venstre) og andreforfatter Lars Gunnar Johnsen. Foto privat
Ordforklaringer

Degenerativ mellomvirvelskive: Strukturell nedbrytning av bindevevet i mellomvirvelskiven i columna kombinert med tegn på akselererte aldersforandringer. Degenerasjonen styres av enzymatiske og angiogenetiske prosesser og er sannsynligvis genetisk betinget.

Tverrfaglig rehabilitering: Rehabilitering av ryggpasienter der ulike yrkesgrupper deltar. Rehabiliteringen består i spesifikke øvelser (fysioterapi og generelle øvelser) og kognitiv tilnærming, der målet er atferdsendring når det gjelder å forholde seg til smerter.

Skiveprotesekirurgi: Den degenererte mellomvirvelskiven erstattes med en protese bestående av to metalldeler, som settes inn parallelt med dekkplatene på virvelcorpus, og en plastdel (polyetylen), som plasseres mellom disse. Hensikten er å fjerne et mulig utgangspunkt for smerter og oppnå en viss bevegelighet i segmentet, til forskjell fra avstiving.

\title{
Kirurgi eller rehabilitering ved ryggsmerter?
}

Operasjon med skiveprotese kan gi bedre funksjon og mindre smerter enn tverrfaglig rehabilitering ved kroniske korsryggssmerter.

Studier har vist at tverrfaglig rehabilitering kan være like effektivt som operasjon med fusjon av antatt symptomgivende korsryggssegmenter. Det er imidlertid ikke tidligere gjort randomiserte studier der man har sammenliknet tverrfaglig rehabilitering og skiveprotese hos pasienter med degenerativ mellomvirvelskive. En slik studie er nå utført av norske forskere (1).

- Vi inkluderte 173 pasienter med korsryggssmerter av minst ett års varighet og degenerative skiveforandringer i nivå L4/L5 eller L5/S1. Pasientene fikk enten innsetting av skiveprotese eller rehabilitering med veiledet fysisk trening med kognitiv tilnærming, sier overlege Øystein P. Nygaard ved Nevrokirurgisk avdeling, St. Olavs hospital, og professor ved Norges teknisk-naturvitenskapelige universitet.

- Innsetting av skiveprotese var mer effektivt enn rehabilitering, vist ved en signifikant større bedring i Oswestry Disability Index 2 år etter behandling. Ved kirurgisk behandling oppnådde $70 \% \mathrm{av}$ pasientene klar klinisk bedring, mot $47 \%$ i rehabiliteringsgruppen. Antallet som kom tilbake i arbeid, var ikke forskjellig $\mathrm{i}$ de to gruppene. Reoperasjon ble utført hos $6,5 \%$ av pasientene i kirurgigruppen.

- Studien tyder på at man kan oppnå bedre resultater når det gjelder funksjon og smerte ved operasjon med skiveprotese enn med tverrfaglig rehabilitering. I begge gruppene var det imidlertid betydelig bedring. Med tanke på den potensielle risikoen ved kirurgi bør tverrfaglig rehabilitering forsøkes først, sier Nygaard.

\section{Forskning på korsryggssmerter}

Artikkelen er skrevet av Christian Hellum, Lars Gunnar Johnsen, Kjersti Storheim, Øystein P. Nygaard, Jens Ivar Brox, Ivar Rossvoll, Magne Rø, Leiv Sandvik og Oliver Grundnes. Hellum og Johnsen er overleger i ortopedi ved hhv. Oslo universitetssykehus og St. Olavs hospital og ph.d.-studenter knyttet til prosjektet.

Studien utgår fra Ortopedisk avdeling, Oslo universitetssykehus, Nevrokirurgisk avdeling og Avdeling for fysikalsk medisin og rehabilitering, St. Olavs hospital, Norges teknisk-naturvitenskapelige universitet, og Universitetet i Oslo.

\section{Erlend T. Aasheim}

erlend.aasheim@legeforeningen.no

Tidsskriftet

\section{Litteratur}

1. Hellum C, Johnsen LG, Storheim K et al. Surgery with disc prosthesis versus rehabilitation in patients with low back pain and degenerative disc: two year follow-up of randomised study. BMJ $2011 ; 342:$ d2786

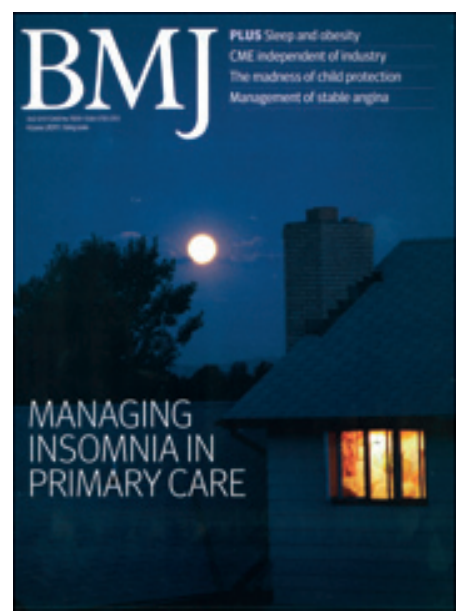

Artikkelen ble e-publisert 19.5. 2011 i BMJ (www.bmj.com), som regnes som en av de «fem store» innen medisinsk publisering, ved siden av New England Journal of Medicine, JAMA, Annals of Internal Medicine og The Lancet 